\title{
Psycholinguistic Peculiarities of the Development of Communicative Competence of Teachers of Secondary Schools
}

\section{Психолінгвістичні особливості розвитку комунікативної компетентності педагогів середніх освітніх закладів}

Eduard Ivashkevych ${ }^{1}$

Dr. in Psychology, Professor
Едуард Івашкевич ${ }^{1}$

доктор психологічних наук, професор

E-mail: natasha1273@ukr.net

https://orcid.org/0000-0003-0376-4615

ResearcherID: V-8872-2018

Lyudmyla Prymachok ${ }^{2}$

Ph.D. in Pedagogical Sciences,

Associate Professor
Людмила Примачок 2 кандидат педагогічних наук, доцент

E-mail: primachok73@ukr.net

https://orcid.org/0000-0002-6591-5223

ResearcherID: F-3874-2019

${ }^{I}$ Rivne State University

of the Humanities

$\square$ 12, Stepan Bandera Str., Rivne, Ukraine, 33000

${ }^{2}$ Educational and Scientific Institute of Public Health of National University of Water Management and Nature Usage

$\triangle 11$, Soborna Str., Rivne, Ukraine, 33000
${ }^{1}$ Рівненський державний гуманітарний університет $\triangle$ вул. Степана Бандери, 12, Рівне, Україна, 33000

${ }^{2}$ Навчально-науковий інститут охорони здоров'я Наиіонального університету водного господарства та природокористування $\square$ вул. Соборна, 11, Рівне, Україна, 33000

Original manuscript received September 20, 2019

Revised manuscript accepted January 28, 2020 


\section{ABSTRACT}

The purpose of the article is to analyze psycholinguistic peculiarities of the development of communicative competence in the structure of social intelligence of teachers and directors of secondary schools in contemporary Ukrainian society.

Methods of the Research. The following theoretical methods of the research were used to solve the tasks formulated in the article: a categorical method, structural and functional methods, the methods of the analysis, systematization, modeling, generalization. Also we used empirical methods - the methods of observation, conversation, testing with the aim to study the structure of communicative competence and social intelligence of teachers; psychological and pedagogical experiment in a form of the research of the development of the structure of communicative competence and social intelligence of teachers.

The results of the Research. In the content of communicative competence of teachers we can emphasize the ability to optimize interpersonal relationships in the group; social sensitivity; a set of communicative skills, behavior patterns and communication techniques; a communicative potential; the interpretative competence. Teachers with a low level of communication competence have characterized by communicative failures caused by a violation of their orientation onto the process of communication: nonmotivated change of speech strategies, mental orientations and the register of speech; failure by the speaker communicate postulates; neglecting by the speaker the linguistic means, which involve the maxim of the tact; unsuccessful choice by the speaker the tone and the register of communication. Scripts of role deixis, explicit and implicit pragmatic constituents in the structure of teacher's communicative competence were formulated, their content was revealed.

Conclusions. Psycholinguistic peculiarities of the development of communicative competence of the teachers and the directors of schools were established: the composite assessment of the teacher's communicative competence positively correlates with social intelligence, reflexive and empathic personal abilities; communicative competence of the teacher depends on the actualization of scripts of role deixis, explicit and implicit pragmatic constituents in its structure, etc.

Key words: communicative competence, the process of communication, a communicative potential, the interpretative competence, the register of communication, communicative failures, social intelligence.

\section{Introduction}

In the XXI century in the sphere of psycholinguistics there are significant changes that allow scientists to speak about changing the scientific paradigm according to the process of studying communicative competence, clarifying its structure and functional characteristics. The main features of contemporary psycholinguistics are anthropocentrism, 
functionalism and communicativeness. System-structural description (and its study) of communicative competence gives a way to anthropo-oriented, functional-communicative and cognitive study of this phenomenon of persons with different individual characteristics, cognitive styles of performing the activities, different intellectual development (Donnikova, 2018; Rubskyi, 2019). All this allows us to state that contemporary psycholinguistics is increasingly becoming a part of a general paradigm of semantic, pragmatic and functional theory, the most important features of which help to study the communicative orientation of all units and categories of psycholinguistic system, and facilitate the actualization of the person in the process of communication (Kalmykova \& Kalmykov, 2015). We understand communicative competence as an inseparable and organic component of a human mind, interconnected with other cognitive, psychic, volitional and other structures and processes (Ivashkevych, 2018). So, in this article we will analyze the peculiarities of explication of communicative competence of teachers with different levels of the development of social intelligence.

In the theory of G. Gardner (1983) there were proposed seven types of intelligence, which were formed by a combination of general personality abilities. To our mind the very concepts of «interpersonal intelligence» and "intrapersonal intelligence», isolated in the theory of G. Gardner, in a great degree correspond to the concept of «social intelligence». Thus, social intelligence is explicated in the structure of cognitive ability of the person to understand himself/herself and the other people; it is due to the development of the abilities of the person according to the level of his/her IQ. Thus, according to the concepts of these authors, social intelligence is directly related to the knowledge of human behavioral information and it was defined as a system of intellectual abilities and characteristics of the person. Particular attention deserves the concepts which define social intelligence through the system of cognitive properties, according to which the effectiveness of communication depends on communicative, cognitive and vital competencies of the person (Tillman \& Louwerse, 2018), a great success of human processing of social information (Kim, Yoon, Kim, Lee \& Kang, 2012).

The generalization of the approaches from the scientific literature to the definition of the concept of «communicative competence» and «social intelligence» allows us to outline the psychological content and 
characteristics of these complicated phenomenon. Thus, we mean social intelligence as the ability that has the following features:

(1) the explication of social intelligence is possible only in the paradigm of the subject-subject, communicative activity;

(2) the amplification of the abilities of social intelligence occurs in the process of interpersonal interaction and communication;

(3) taking into account the multidimensional nature of the abilities of social intelligence, it is evident that social intelligence contains a certain complex of capabilities that are clearly coherent with each other, which are rather stable for this or that person;

(4) the development of this group of abilities is due to the process of socialization of the person, the influence of both internal resources and characterological characteristics of the person, gender differences and the impact of the environment on a person;

(5) a communicative competence is not a constant, stable characteristic, it varies during our life and can be changeable in different situations of social interaction.

According to this we believe that the structure of social intelligence of the person (and also the structure of social intelligence of the teacher) includes prognostic and communicative competence.

The problems of the development of communicative competence of the person were analyzed in the researchers (Baklushinskiy \& Belinskaya, 1998; Bandura, 2000; Gergen, 1995). Scientists in their theoretical conceptions identify communicative competence and social intelligence, and this, for a certain period of time (mid-twentieth century), has become one of the reasons for the similarity of the semantics of the data definitions, which, according to our persistent beliefs, are not identical. Also we think that communicative competence must be included into the context of social intelligence. In such a way, if the structure of social intelligence of the person of a teacher includes communicative and prognostic competences, then social intelligence should be considered as the integral part of social competence of the person (Kudryavtseva, 1995). However, we believe that the attribution of social competence to the structure of social intelligence of the person is unlawful, because social intelligence is a slightly narrower category than social competence, and the structure of social intelligence does not 
include, for example, ethnic and national-cultural, civic identities, etc., whereas they are substructural components of social competence (Ball \& Medintsev, 2011), which determine the peculiarities of the development of this category.

The analysis of scientific researchers allows us to conclude that social intelligence and communicative competence are closely interrelated, but not identical categories, because social intelligence is distinguished as the means of human knowledge about social reality, and communicative competence is the product of this knowledge, but with its own peculiarities and characteristics which we'll try to describe in our article.

The main differences of communicative competence and social intelligence are, first of all:

(a) in the ways of the development (if the development of communicative competence is facilitated by the acquisition of knowledge, communicative skills and abilities by a person and the actualization of personally significant experience, then social intelligence also (in addition to knowledge and experience) develops through the development of communicative properties, mechanisms of mental regulation, adaptive mechanisms of the psyche, self-control, self-regulation, stress resistance of the person;

(b) in the content characteristics (communicative competence is much more narrower concept than social intelligence, because communicative competence contains a set of certain communicative abilities and characteristics, and social intelligence is a personality neoplasm of the subject);

(c) in the functional plan of the representation of these two categories (the main functions of communicative competence are: skills of providing interpersonal orientation, communicative adaptation, integration of general social and personal experience of the person in the paradigm of communicative situation, also communicative tolerance; the functions of social intelligence are: ensuring adequacy, adaptability in changing conditions of social reality, planning interpersonal events and forecasting their development, updating the motivation of the person, acquisition of social competence, self-development, self-knowledge, self-education, etc.). 
We consider «social intelligence» as a broader content category, both in content and in functional plans, while communicative competence plays the role of so-called cognitive determinants of the development of social intelligence.

We mean that communicative competence of each person can be developed within so called socio-cultural space which was objectively set. In this space certain norms of behavior and social interaction have already been formed. These steel norms are like crystallized frames, archetypes in the structure of social intelligence.

Our understanding of social intelligence is quite psycholinguistic. We'll try to explain our point of view. We consider the concept of «intelligence» in the broad and narrow senses, but both of them are psycholinguistic in their context. If we talk about the broad meaning of «intelligence», we mean about only one intelligence, the intellectual sphere of the person in general. In this sense, the intelligence of a person can be described as a hierarchical system that has several levels. The first level is the level of functioning of cognitions, to which psychologists refer the main psychical processes (sensation, perception, memory, attention, which, in turn, "control» the course of cognitive activity (Gardner, 1993; Kihlstrom \& Cantor, 2017)), as well as thinking and imagination (Guilford, 1986; Kalmykova, 2016), speech and dialogical interaction (Zasiekina, 2006). The second level of intelligence is the level of metacognitions (metacognitive integrators, «secondary» mental processes), among which the main ones are intellectual initiation (self-statement of the problem), reflection, decentralization, intellectual strategies and abilities (abilities and competences), as well as metacognitive monitoring, intuition, intellectual atheist (values, meanings) (Collins, 2014; Fedorova, 2009; Tillman \& Louwerse, 2018). The first and the second levels of intelligence, in our opinion, are fully understood by the person who carries out intellectual activity. The third level of intelligence amplifies the characteristics of both the first and the second levels, while intellectual activity is carried out mainly at an unconscious level, a level that approximates a person to use of automated skills and abilities. The next, the fourth level, is the level of meta-intellectual activity, which explodes the creative achievements of the person. Thanks to this fourth level of intelligence a person is able to establish interaction not only with different objects and other people, but also with the world as a whole, thus expanding 
the limits of his / her intellect and starting a dialogue with the creative beginning of the world.

So, communicative competence is fixed on the II-nd level of social intelligence - the level of metacognitions. Also we highlight the main functions of social intelligence of teachers and directors of educational establishments. These functions are also psycholinguistic. The first one is «understanding other people», which provides foresight in interpersonal relationships, the effectiveness of understanding of social situation in general and the situations of interpersonal interaction in particular. The function of «adaptation to the requirements of the society» is also dominant. We've to note that this function provides the ability of the person to use psychometric intelligence in order to adapt to the society effectively. The indicator of highly developed social intelligence is the effectiveness of the use of individual metacognitive strategies while performing social tasks and solving various problems.

The next dominant function of social intelligence of teachers and directors of educational establishments is the function of «deep knowledge of the behavior of social objects». This function ensures the ability of the person to communicate with other people, the ability to predict the consequences of other people's behavior; the ability to distinguish essential features in the content of verbal and nonverbal reactions of people; the ability to understand changes in the meaning of verbal and nonverbal reactions of people depending on the context of a particular situation; the ability to understand the logic of the development of the situations of interpersonal interaction, to understand the value of the behavior of other people.

Also we've to underline cognitive and behavioral functions of social intelligence. In particular, the cognitive function involves the assessment of the prospects of the person's development; understanding of people; to provide social insight; knowledge of social norms. Behavioral functions include: the ability to co-operate with other people; social adaptation; empathy in interpersonal relationships.

So, under the communicative competence of a teacher we will understand the complex of personal formation, which includes communicative abilities and possibilities, psychological knowledge in the field of communication, personal characteristics, psychological states which accompany the process of communication as a whole. 
Therefore, the communicative competence of a teacher will be defined by us as the appropriate pragmatic use of social knowledge and social experience by specialists in the context of professional relationships. In the paradigm of this understanding we can say that the behavior of teachers corresponds to the context of professional interaction, related to the nature of the relationship between a teacher and a pupil. It is indisputable that in order to achieve competent relationships successfully it is necessary to know the principles and the rules of communication, as well as adequate ways of their implementation. A high level of the development of communicative competence implies, first and foremost, the teacher's ability to maintain «desired» relationships with schoolchildren. Therefore, the main focus in our research should be fixed on the study of the relationships which are formed in the dyad «a teacher - a pupil». As a criterion for the development of communicative competence we consider a high level of affiliation and control of the process of communication, and to assess and classify strategies for adopting social views as personally significant ones it is necessary to take into account the peculiarities of the teacher's social intelligence.

\section{Methods and Methodical Instrumentation of the Research}

At this stage of the empirical research were participated 395 teachers of secondary schools of different regions of Ukraine and 8 directors of these school. At the beginning of the research we formulated the hypotheses that the level of the development of social intelligence of the teacher of secondary school will depend on the professional category (which he/she has; the category will show the degree of professionalisms of the teacher), the type of discipline of this teacher (to which cycle of disciplines belongs this or that subject), and (it is the main) from the psychological type of the personality and from the gender characteristics of the person. For the convenience of describing the results of the research (hence the description of those results that have or do not have a statistically significant difference among representatives of different groups), all respondents were distributed by large and small experimental groups. So, when the results of respondents within a single large experimental group had a 
statistically significant difference, they were described separately, taking into account their formation within small groups; in the case when there was no such difference, the results of all respondents were described in the paradigm of one large specially formed group. In such a way, all 403 respondents were divided into the following groups:

(1) S group - 103 teachers of the III-d and the II-d categories (professional experience is from 5 to 10 years, the age is up to 30 years). This group includes: 56 teachers of secondary schools No 5, No 15 of Rivne town, 23 teachers of Shpanivska and Alexandria secondary schools of Rivne region, 24 teachers of secondary schools No 45, No 96 of Odessa city. In turn, all teachers of this group were divided into subgroups, depending on the discipline they teach:

- S1 group includes 34 primary school teachers (of which 4 teachers are men and 30 ones are women);

- S2 group includes 35 teachers of teenagers who teach the natural sciences and humanities (of which 17 teachers are men and 18 ones are women);

- S3 group includes 34 teachers of senior pupils of the physical and mathematical cycle (of which 17 teachers are men and 17 ones are women);

(2) $\mathrm{N}$ group includes 108 teachers of the I-st category (professional experience is from 10 to 15 years, the age is from 30 to 35 years), among them there are 47 teachers of secondary schools No 5, No 15 of Rivne town, 30 teachers of Shpanivska and Alexandria secondary schools of Rivne region, 31 teacher of secondary schools No 45, No 96 of Odessa city. Teachers of $\mathrm{N}$ group were divided into such micro-groups:

- N1 group includes 39 primary school teachers (all of them are women);

- N2 group includes 37 teachers of teenagers who teach the natural sciences and humanities (among them there are 17 men and 20 women);

- N3 group includes 32 teachers of senior pupils of the physical and mathematical cycle (16 of them are men and 16 are women);

(3) M group includes 110 teachers of the highest category (professional experience is from 15 years and more, age is from 35 years old and elder); among them there are 55 teachers of secondary schools 
No 5, No 15 of Rivne town, 22 teachers of Shpanivska and Alexandria secondary schools of Rivne region, 33 teachers of secondary schools No 45, No 96 of Odessa city. Teachers of M group were divided into such micro-groups:

- M1 group includes 26 teachers of primary school (all of them are women);

- M2 group includes 42 teachers of teenagers who teach subjects of physical-mathematical cycle (there are 22 men and 20 women);

(4) P group includes 74 teachers-methodists and eight directors of secondary schools (their professional experience is 35-40 years, age is 40-47 years old), among them there are 32 teachers of secondary schools No 5, No 15 of Rivne town, 13 teachers of Shpanivska and Alexandria secondary schools of Rivne region, 29 teachers of secondary schools No 45, No 96 of Odessa city. This group also includes 8 directors of secondary schools (among them there are directors of schools, noted above, and also the director of Zdolbuniv schools No 5, 7 of Rivne region). Teachers of $\mathrm{P}$ group were divided into such micro-groups:

- P1 group includes 13 primary school teachers (all of them are women);

- P2 group includes 30 teachers of teenagers who teach the natural sciences and humanities (among them there are 12 men and 18 women);

- P3 group includes 31 teachers of teenagers and senior pupils of the physical and mathematical cycle (among them there are 15 men and 16 women);

- P4 group includes 8 directors of secondary schools (among them there are 4 men and also 4 women).

Distribution of teachers into groups and micro-groups was carried out using the method of randomization (technology of pair design), which allowed us to equalize the number of men and women in each micro-group (except for micro-groups, which included primary school teachers, because there were no men among this category of teachers).

In order to identify the structure of communicative competence of a teacher we used the

(1) "Questionnaire to diagnostic the ability to manage selfpresentation in the process of communication» (Snyder, 2016), 
Psycholinguistic Peculiarities of the Development of Communicative...

and

(2) «Methods to diagnostic communicative tolerance» (Boiko, 2017).

(3) With the aim to diagnose the level of the development of social intelligence of teachers we used the test of J. Gilford and M. O'Sullivan "Research of Social Intelligence», adapted by O.S. Mykhailova (Guilford \& O'Sulliven, 2007).

\section{The Results of the Research and their Discussion}

At the first stage of our research we analyzed the results obtained by teachers' communicative competence. In general, the comparison of the results obtained by the development of communicative competence of teachers in groups of respondents with professional experience from 0 to 10 years and from 10 and more years suggests that communicative competence does not depend on the length of the professional activity in a whole, but also does not depend on the gender characteristics of respondents, but has a direct positive correlation with social intelligence of teachers and headmasters.

The results obtained by us in all groups of teachers suggest that the availability of basic communication skills significantly increases the ability of each specialist to engage himself/herself in competent relationships, but these communication skills are not a guarantee of such relationships (because the latter depends, to a large extent, on a general professionalism of teachers). Thus, communicative competence is not so much associated with a high level of communication skills and effective professional activities, but with the ability to maintain interpersonal relationships at the highest level.

It was determined that the communicative qualities of teachers of groups S1-S3 include: the ability to corporation and group work (0.6834); behavioral orientations in conflict situations (0.6402); social competence in the process of achieving goals (to make social contacts (0.6324), sociability (0.6501), the power of persuasion (0.5831), charm $(0,4701)$, the way to keep yourself confident $(0.4314))$. Motivational and volitional qualities of a teacher are also important (the pursuit of success (0.6714), the focus on achievements (0.7311), firmness (0.7402), selfdetermination (0.5108)), and motivational and moral qualities (honesty 
(0.5301), decency (0.5516), conscientiousness (0.5727), adherence to principles $(0,5002)$, responsibility $(0,5246)$, attention to people $(0,5425))$.

The empirical research shows that quite diverse elements should be included into the structure of communicative competence. At the same time, among their diversity everyone can clearly distinguish specific abilities, for example, certain personal characteristics, psychological skills, as well as individual cognitive communication styles.

Thus, to the structure of communicative competence of a teacher we have included a set of abilities, possibilities, psychological knowledge and communicative traits of the person which are explicated in different situations of communication. Carrying out its structural and semantic analysis, it should be emphasized that communicative competence will be shown at two interrelated levels, such as operational-technical or behavioral one, and deeper, personal-semantic level.

Thus, in the content of communicative competence of teachers of groups S1-S3 and N1-N3 we can emphasize the ability to optimize interpersonal relationships in the group (0.7134); social sensitivity (socioperceptual skills and sensitivity to the perception of another person; 0.6918); influencer factor (as a set of communicative skills, behavior patterns and communication techniques; 0.6831), personal characteristics that make up the communicative potential of a teacher $(0.6501)$.

In order to optimize interpersonal relationships in the group of pupils, teachers with a high level of communicative competence have used the technique of role deixis - it is the indication of participants (the speaker and the addressee) into a speech act, as well as the involving other people into the process of communication (we mean such people who are not real participants of this act of communication). These are the so-called Ich-deixis and Du-deixis (Buller, 2000). This type of deixis defines the communicative roles of the participants in the interaction and is expressed by different types of pronouns (I, you, he, she, my, yours, him, etc.).

In spite of performing a function of pointing on the communicative roles of participants in the process of communication, role-playing means of deixis, as well as other practical means of discourse, may be burdened with a number of other semantically-pragmatic communicative (or quasi-communicative) meanings. In such a way they can point to different types of groups of participants in communication or persons who are not real participants of this act of communication. For example, 
the lexical unit «we» unites into one role group the speaker, the addressee and/or the person who is not a real participant in this act of communication; «you» means a group to which the speaker says but to which he/she does not belong as the addressee does; a lexical unit «they» performs a group that is neither the addressee nor the speaker.

Such kind of connotation of role-playing deixis is largely determined by semantic and pragmatic features, such as quantity (I, you, he, we, they, etc.), conditions of certainty/uncertainty (I, you, someone, something, etc.). accessories (mine, yours, his, theirs).

The means of role-playing deixis in the context of specific paradigm and in this or that situation of communication may also «hint» about the communicative positions of the participants of speech act. For example, the pronoun «you» may indicate, in addition to the direct roleplaying function, that the speaker attaches the addressee to a particular group of people within which there is not a speaker; also such kind of situation can show the respectful attitude to the addressee; it also may indicate that the addressee plays the role of an Adult or a Parent (but not a Baby) (Bern, 2002).

For example, at the English lesson, the theme of which is «Types of nonverbal communication and body language», teachers with a high level of communication competence often use the means of role-playing deixis:

Touch

We communicate a great deal through our touch. You have to think about the messages given to us by the following: our firm handshake, our timid tap on the shoulder, our warm bear hug, our reassuring pat on the back, our patronizing pat on the head, his or her controlling grip on your arm.

\section{Space}

Have you ever felt uncomfortable during a conversation because the other person was standing too close to you invading your space? We all have a need for physical space, although that need differs depending on our culture, his or her situation, and our closeness of the relationship. You can use your physical space to communicate with many different nonverbal messages, including your own signals of intimacy, aggression, dominance or affection.

Voice

We communicate with our voices, even when we are not using our own words. Our nonverbal speech sounds such as tone, pitch, 
volume, inflection, rhythm and rate which are important elements of communication. When we speak, other people «read» our voices in addition to listening to our words. Our nonverbal speech sounds provide subtle but powerful clues into our true feelings and what we really mean. We have to think about how tone of our voice, for example, in such a way we can indicate sarcasm, anger, affection, or confidence».

Also the important role for teachers of S1-S3 and M1-M2 groups is such a fact that linguistic knowledge (0.5004) and speech creative skills (0.5246) has to be formed within the communicative competence. Thus, a high level of linguistic knowledge gives the idea of the language having been used in different situations of communication. In turn, a high level of the development of speech and creative skills provides in a great degree effectiveness in communication, the adequacy of understanding and construction of different types of texts, the effectiveness of the use of different speech means.

Speech and creative skills of teachers with a high level of communicative competence are characterized by the use of pragmatic constituents in speech acts - they are formed according to semanticpragmatic characteristics of words, as well as expressive intonation. The semantic content of these statements can be conveyed by: (1) implied information; (2) information of explicit content. In such a way pragmatic constituents have the following quasi-communicative peculiarities: (1) they are outside the category of truth/false. The most important pragmatic category that unites them is the sincerity/insincerity of the expression of emotions or feelings, open/hidden form of demonstration of the person's behavior; (2) pragmatic constituents describe the state of the speaker, but they do not express it; (3) these categories are intentional, in such a way they are expressed by a particular speaker and they imply a specific addressee; (4) pragmatic constituents are less institutionalized, although sometimes they may express social constraints; (5) pragmatic constituents are less dependent on the context, denoting a particular specific sphere of feelings, desires, wills, etc.; (6) pragmatic constituents can have a certain number of transformations, primarily related to the categories of time and space.

Here is the example of pragmatic constituents which explicate explicit content. For example, we'll show a teacher's monologue at the English lesson «Proverbs and Sayings which characterize the activity of the person». 
Teacher: «From time to time proverbs and sayings have changed, forgotten ones have died and new patterns have been born, and there has taken a place continuous grinding, expansion, narrowing or changing of values, their semantics and so on. The origin of proverbs and sayings is dominant at the period of the development of agricultural activity of people. Proverbs and sayings are associated with the process of observing by the person his/her work or activity, and this process is one of the ancient.

(1) As a man sow, so shall he reap (Не копай яму іншому, бо сам упадеш).

(2) Sow a thought and reap an act (Посієш думку - пожнеш вчинок).

(3) Strike while the iron is hot (Куй залізо, поки гаряче).

(4) Early sow, early mow (Рано сієш - рано і пожнеш. Хто перший сіє, той перший збирає).

(5) Make hay while the sun shines (Коси коса, поки poca).

(6) One plows, another sows - who will reap, no one knows (Один оре, інший сіє, а кому врожай збирати - не знає ніхто).

Working activity of the person has been developed very slowly, and also changed were slowly. This stability in a great degree influenced the development of established views on the activity, its results, methods of doing the work. All these factors were reflected in the folklore. The proverbs were emphasized the eternal truth of the person's activity as the basis of our life.

Let's compare:

(1) A man of words and not of deeds is like a garden full of weeds. (Противник справ, любитель слів схожий до саду без плодів. Хто багато говорить, той мало творить).

(2) No sweet without some sweat / Nothing is gained without work (Без труда нема плода).

In a great degree striking in the proverbs and sayings it was shown the development of crafts.

(1) The cobbler should stick to his last (Знає майстер, що робить).

(2) Let every tailor stick to his goose / Every man to his trade (Не берися не за своє діло).

For centuries, years, and from mouth to mouth useful tips have been passed, and even nowadays they have become relevant, though the characters have been changed: 
(1) Never look at half-done work (Дурням та дітям пів роботи не показують).

(2) Always lend a helping hand (Завжди допомагай іншим).

(3) Never leave a woman to do a man's job (Ніколи не залишай жінці чоловічу роботу).

(4) Act today only tomorrow is too late (Роби сьогодні, бо завтра пізно)».

The examples of pragmatic constituents that express implicit content information (at the English lesson «Types of nonverbal communication and body language») are:

More transient expressions often reveal feelings that a person is not intending to communicate or even aware of. Here are just a few to warm you up:

\begin{tabular}{llll}
\hline Pensive & Amused & Sad & Barely tolerant \\
Warning & Pouting & Anxious & Sexually attracted \\
Startled & Confused & Sleepy & Intoxicated \\
\hline
\end{tabular}

There are many kinds of gestures:

\begin{tabular}{lll}
\hline Clenching fist & Shaking a finger & Pointing \\
Biting fingernails & Tugging at hair & Squirming \\
Rubbing chin & Smoothing hair & Folding arms \\
Raising eyebrows & Pursing lips & Narrowing eyes \\
Scratching head & Looking away & Hands on hips \\
Hands behind head & Rubbing nose & Rocking \\
Sticking out tongue & Tugging earlobe & Waving \\
\hline
\end{tabular}

However, implicit pragmatic constituents also indicate a high level of formation of the communicative competence of a teacher, firstly, as a result of the teacher's explication of sincerity in expressing emotions, feelings, with the aim of depicting a hidden form of demonstration of his/her behavior. Secondly, pragmatic constituents encourage pupils to demonstrate their own emotions, thoughts, experience and feelings. The latter, to our mind, facilitates the development of communicative competence of the schoolchildren themselves.

For teachers of groups S1-S3 and P1-P4 we have to emphasize that they have so-called «transformative» nature of communication skills (0.6422), also the individuals can easily perform the ability to transform knowledge and experience in completely new situations of communication, as well as the ability to design new systems of ways 
and techniques for solving specific problems of communication. As a component of the communicative competence of a teacher, we also consider the individual style of communication of the person $(0.5817)$.

For example, the teacher's explanation of the correct pronunciation of the words: "In nouns and adjectives the emphasis usually falls on the first syllable, that's why we have a pair of homographs in the contemporary English: absent - absent, object - object; record - record, upset - upset.

In words with a lot of syllables the emphasis usually falls on the third syllable from the end of the word (usually with suffixes -al, -ar, -ence, etc.): habitual, peculiar, experience.

Such a place of emphasis is explained by the disappearance of a final unstressed syllables in the borrowed word and the transition of the second-role emphasis to the place of the main one:

Latin beneuolentia $>$ benevolent (ia) $>$ benevolent, later is benevolence

(from -ence < Latin -entia, we can compare with benevolence).

In words with suffixes -ary, -ency the unstressed syllables have taken a place:

Latin auxiliarius $>$ auxiliary (from $-\mathbf{y}<$ Latin -ius).

In such words the emphasis usually falls on the fourth from the end syllable».

In this case such an explanation by the teacher of the correct pronunciation of words is quite new, unusual for pupils, which tells about the ability of the teacher to design new systems of methods and techniques for solving specific problems of communication. First of all, we tell about pragmatic performatives - these are statements that have a clearly pragmatic meaning. Pragmatic performatives are characterized by the fact that they are used in unchanged, sufficiently visualized form, do not have conventional, established transformations in the paradigm of the linguistic code.

As the empirical results show, it is obvious that communication skills of a teacher combine the ability to orientate in different situations of communication, in the variety of interactions that have being arisen in this process, as well as in the individual psychological peculiarities of partners of communication.

We were also diagnosed a high level of interpretative competence of the teachers. Such interpretative competence is a structural component 
of communicative competence. This component is necessary for the professional activity of specialists in this field of the activity, because people belonging to different social, ethnic, professional and age groups, in the absence of a proper level of the development of interpretive competence do not perceive messages that are reproduced by other people and sent to this specialist at semantic and emotional levels.

The structure of communicative competence of teachers of P1-P4 groups would also include the personal component as a set of individual qualities: high motivation for successful communication (0.6114), empathy (0.5909), emotional stability (0.5844), stability of self-esteem (0.5602), positive self-concept (0.5402), congruence (0.5318), flexibility $(0.5264)$, creativity $(0.5118)$, reflexivity $(0.5004)$, curiosity $(0.4831)$, initiative (0.4716), high control of the process of communication (0.4611). Thus, these results help us to determine the main components in the structure of communicative competence, such as: communicativeness, willingness to communicate, the ability to influence another person, positive self-concept, communicative orientation, communicative abilities, communicative awareness, individual style of communication. Thus, in order to form the communicative competence of a teacher, it is necessary to develop the following personal qualities: sociability, empathy, expression, locus control, self-esteem, emotional stability, intra- and extra-individual orientation of the person.

Teachers with a low level of communication competence have characterized by communicative failures caused by a violation of their orientation onto the process of communication. This type of communication failure is related to the non-normative speech behavior of the addressee and can be considered indicative of its substantive characteristics. Let us analyze the subtypes we have singled out for teachers.

(1) Non-motivated change of speech strategies, mental orientations and the register of speech. It is a matter of not following by one of the maxims of «normal» communication, which can be explained in such a way: «Follow one way of speaking, one genre, one register». The result of neglecting by the speaker this maxim may be misinterpretation of the information by the addressee, or, what is more important, misunderstanding of illicit intentions by the orator. In this case a sharp change of speech and thinking strategies can cause difficulties for the listener to interpret the illusory purpose of the speaker, his/her 
desire by means of language means to change the addressee's perception of the outside world (some certain information), to encourage him/her to make the necessary, appropriate to his/her point of view changes (request or order), facilitating the speaker to expectation of certain events or actions in the future (promise, warning).

A sudden change of the speaker's speech, his/her thinking strategies may concern not only the content of the information, but also its axiological, ethical aspects. The latter is also a source of confusion for the addressee, an obstacle to his/her interpretive activity.

Communicative difficulties can also be caused by a non-motivated change in the mental (for example, in ideological) orientations of the speaker. Such cases make it possible to formulate the maximum of commencement of communication with unknown person: «The address to unknown person should be logically motivated (justified) and, as a rule, be accompanied by the usual means of etiquette for him/her».

(2) Failure by the speaker communicate postulates. One of the reasons of perhaps the greatest number of communicative failures is non-compliance by the speaker the rules of speech cooperation with the addressee (we mean the code of speech behavior, postulates of speech communication). By «postulates of speech communication» we understand information contained in a speech act, such as: (a) the information that can be considered as explicit one, which forms the logical content of the utterance; (b) implicit information which is contained in so-called implications. So called implications are divided into conventional, content-related word forms or phrases, and nonconventional or so-called «implications of discourse», related to the content of the utterance, not directly but indirectly, which become quite understandable, based on the laws of communication, mastered by the person in a childhood during the process of linguistic socialization.

We believe that these postulates can make the possibilities for the speaker to embody his/her communicative concept without resorting to verbal expressions which can be understood by the listener with their assistance, based on the direct meaning of the utterance. According to these speech principles communicative strategies of the speaker and the addressee are constructed, as well as their interpretative activity. Violation of any of these maxims may cause a communicative failure or a signal of the need for the indirect «reading» by the addressee the text or the message, or the information of the speaker. 
(3) Neglecting by the speaker the linguistic means, which involve the maxim of the tact, which can be the result of ignoring the implications of indirect speech, that causes the direct, explicit «reading» of the sense of the utterance. Such cases indicate that etiquette is a manifestation of socialization, interest in another person, not in himself/ herself. The more remote the teachers are from their pupils, the more necessary is the implementation of the etiquette. At the same time it is necessary to emphasize on a measure of etiquette: the smaller is such a measure (as it is accepted in a certain society), the stronger the measure of etiquette will produce the effect of disrespect for the partner of communication; at the same time, too much can cause a pragmatic paradox when the partners do not want to be polite, but in the end both of them accept the opposite position (or point of view) of his/her partner of communication. It should also be emphasized that in some cases the display of politeness may be interpreted as bullying, ridicule or even indirect speech act.

(4) Unsuccessful choice by the speaker the tone and the register of communication. We have to emphasize that a great number of communicative failures caused by the insufficient orientation of the addressee on the process of communication can be explained by his/ her choice of tone and the register of communication, which in this case do not correspond to the actual situation. It should be noted that the tone of the teacher is a leading concept of the communication process, which unites in its structure, on the one hand, the attitudes of the partners of communication to surrounding reality, and, on the other hand, underlines their psychological orientations. Accordingly, a non-conflicting, harmonious tone is a necessary feature of each style or type of communication. Violations of the tone of communication cause a corresponding psychological reaction and they are accompanied by typical speech formulas which are the reactions of the partner of communication: «I do not quite understand your tone», "Why do you say to me with such a tone?», «Why should I answer you if you speak to me with such a tone?».

At the second stage of our research we'll analyze the results of the development of social intelligence of teachers. The results of the levels of the development of social intelligence of the teachers indicate that the level of the development of social intelligence does not depend on the level of teachers' qualification, such as on the length of period 
of work at school, the age of the respondent, etc. The social intelligence of the teacher depends, first of all, on the gender characteristics of the respondents, as well as on the subjects' area of their professional activity that the teacher is engaged since the end of the university. Therefore, we predicted that the level of the development of social intelligence of a teacher would depend on the psychological type of his/her person, and this type, in turn, would predetermine the choice of the respondent for one or another sphere of his/her professional activity (for example natural sciences or humanities or physics and mathematics, the choice of the profession of the teacher of primary school, etc.).

Consequently, the empirical stage of this research envisaged the definition of a problem area of the difficulty of understanding other people by school teachers and directors of schools. The research was provided in all the groups at the same time, involving all participants into this experiment. Respondents were offered a questionnaire developed by us (Ivashkevych, 2018), which contained 80 statements that showed exactly what difficulties of understanding of other people there were. The content of their responses allowed us to identify and generalize the typical difficulties of understanding. The instruction was proposed to evaluate each statement, which indicated the complexity of understanding on a five-point scale.

The most characteristic difficulties of understanding of other people for male respondents were: the spheres of family and personal life for $90,04 \%$ of respondents were important, but this category occupied the third place, while to the first and second places the male teachers placed «recognition and acceptance of my personality in the team» $(92,46 \%)$ and «understanding colleagues in the professional activity» $(83,11 \%)$. Also, for male teachers the material difficulties are also very important $(92,12 \%)$.

The fifth, which is the most significant problem for male teachers is the interaction associated with the achievement of the position of a leader (the head of the institution or establishment). This problem was evidence for $73,17 \%$ of respondents.

Also, there are significant difficulties for male teachers with a higher qualification (getting the highest professional category). For $87,92 \%$ of respondents, significant difficulties in this regard relate to the state of anxiety, conflict situations in their favorite professional affairs. 
The next, the seventh ranked place was the difficulty of interaction associated with socio-political life (71,34\% of respondents).

The eighth place in terms of the importance of the complexity of interaction among male teachers are the problems associated with the expression of creativity in the sphere of professional activities. About $88,01 \%$ of the answers of male teachers indicate actual difficulties of this nature. And finally, the ninth place among male teachers got the difficulties of interaction associated with the spiritual development of their person, such responses there were $85,16 \%$.

Thus, the results we obtained suggested that male teachers and male directors had the same difficulties in understanding: in personal and family life, in professional work with colleagues in the process of professional activity, with those people who can help in achievement of material wealth. Extreme difficulties are related to the search for like-minded people and friends, as well as respect and recognition in the group.

Women-teachers and women-directors of schools have principal ranks for difficulties related to the material situation in their family $(83,75 \%$ of respondents), the second place is for family and personal life $(90,02 \%$ of respondents). The third ranked position was divided between the difficulties of upgrading the qualification/receiving the category $(83,94 \%$ of female respondents) and the understanding of their colleagues $(92,33 \%$ of female respondents). Difficulties associated with the recognition and acceptance of the respondent in the team occupied the fourth place; in this group such kind of answers there were about $90,17 \%$.

About $83,19 \%$ of respondents among female teachers point to problems of career-related interactions. In this group the difficulty of understanding which has a close relationship with the manifestation of leadership qualities, the achievement of a leader's position got the seventh place $(86,90 \%$ of respondents). Difficulties in the process of interaction were associated with the expression of creativity in the sphere of professional activities, taken the eighth place, $85,11 \%$ of respondents were noted as the most significant one. The difficulty of interaction in the field of socio-political activity among female teachers and female school principals took the last - the ninth place. Thus, $87,97 \%$ of respondents stressed the importance of assessing these difficulties. 


\section{Conclusions}

Thus, the obtained results allowed to draw some conclusions. For teachers and directors of secondary schools, regardless of gender, it is clearly problematic to establish any contact with colleagues in the process of professional activity, teachers perceive almost any interaction in the professional sphere as personally significant. The biggest challenges are the new educational environment and personal life that is crucial to succeed for teachers and school directors. Conditions and requirements of the educational environment are unusual, the circle of communication with colleagues in the sphere of the professional activity is significantly different from the family and personally significant circle, adaptation to them lasts for a long period of time.

At the same time, young teachers and school directors, as the results showed, often think about career and career advancements in the present period of time, about achieving leadership positions - this seems to be extremely relevant to them.

The last ranking position regarding the lack of understanding problems was associated with the manifestation of socio-political activity. It's obviously that it can be explained by the lack of a real participation of the most teachers in democratic movements, the isolation of educational subcultures from the life of Ukrainian society. Teachers, as a rule, do not take part in making political decisions. Perhaps this fact is a problem not for the administration of schools and their teaching staff, but also requires the attention of public authorities.

Also, psycholinguistic peculiarities of the development of communicative competence of the teachers and the directors of schools were established:

- the composite assessment of the teacher's communicative competence positively correlates with social intelligence, reflexive and empathic personal abilities;

- communicative competence of the teacher largely depends on the creation of positive conditions for the implementation by a specialist high professional, creative activities that will actualize the development of divergent abilities of the teacher, will allow him/her creatively and holistically perceive the professional situation, the situation of interpersonal interaction 
on the basis of enrichment of typical social meanings by the diversity of individual values and person's senses;

- communicative competence of the teacher depends on the actualization of scripts of role deixis, explicit and implicit pragmatic constituents in its structure.

The prospect of further researches is in providing detailed research of the qualitative characteristics of cognitive styles performed by specialists of other professions by their activities, to study features of the mnemonic and empathic aspects of social intelligence, which determine the level of the development of communicative competence of a teacher.

\section{References}

Baklushinskiy, S.A., \& Belinskaya, E.P. (1998). Razvitie predstavlenij o ponyatii «socialnaya identichnost» [The Development of Ideas about the Concept of «Social Identity»]. In V.S. Sobkin (Ed.), Jetnos. Identichnost. Obrazovanie Ethnos. Identity. Education (Vol. IV (VI), pp. 64-85). Moscow: CSO RAO [in Russian].

Ball, G.O., \& Medintsev, V.O. (2011). Osobystist yak indyvidualnyi modus kultury i yak intehratyvna yakist osoby [The Person as an Individual Mode of Culture and as Integrative Quality of a Person]. Horyzonty osvity - Horizons of Education, 3, 7-14 [in Ukrainian].

Bern, E. (2002). Ljudi, kotorye igrajut v igry. Igry, v kotorye igrajut ljudi [People who play games. Games are Played by People]. Moscow: FAIR-PRESS [in Russian].

Buller, K.K. (2000). Teorija jazyka. Reprezentativnaja funkcija jazyka [Theory of the Language. Representative Function of the Language]. Moscow: Progress [in Russian].

Bandura, A. (2000). Teoriya socialnogo naucheniya [The Theory of Social Learning]. St. Petersburg: Eurasia [in Russian].

Boiko, V.V. (2017). Metodika diagnostiki kommunikativnoj tolerantnosti [Methods to Diagnostic Communicative Tolerance]. URL: psylist.net/praktikum/boiko.htm [in Russian].

Collins, M.X. (2014). Information Density and Dependency Length as Complementary Cognitive Models. Journal of Psycholinguistic Research, 43 (5), 651-681. https:// doi.org/10.1007/s10936-013-9273-3

Donnikova, I.A. (2018). Nravstvennyj poisk v multikulturnoj kommunikacii [Moral Search in Multicultural Communication]. Anthropological Measurements of Philosophical Research, 14, 30-41 https://doi.org/10.15802/ampr.v0i14.150545 [in Russian]

Fedorova, E.A. (2009). Socialnyj intellekt kak faktor formirovaniya otnosheniya k socialno znachimym ob'ektam u predstavitelej razlichnyx etnicheskix grupp [Social Intelligence as a Factor in the Development of Attitudes Towards Socially Important Objects Among Representatives of Different Ethnic Groups]. Candidate's thesis. Yaroslavl [in Russian]. 
Psycholinguistic Peculiarities of the Development of Communicative...

Gardner, G. (1983). Frames of Mind: The Theory of Multiple Intelligences. London: Heinemann.

Gardner, G.E. (1993). Multiple Intelligences: The Theory in Practice. New-York: Basic Books.

Gergen, K. (1995). Dvizhenie socialnogo konstrukcionizma v sovremennoj psixologii [The Movement of Social Constructionism in Contemporary Psychology]. Moscow: Science [in Russian].

Guilford, J.P. (1956). The structure of intellect. Psychological Bulletin, 53 (4), 267 293. https://doi.org/10.1037/h0040755

Guilford, J., \& O’Sulliven, M. (2007). Test «Socialnyj intellect» [Test «Research of Social Intelligence»]. URL: lib.chdu.edu.ua/pdf/posibnuku/160/41.pdf [in Russian].

Ivashkevych, E.Z. (2018). Psykholohiia sotsialnoho intelektu pedahoha [The Psychology of Social Intelligence of a Teacher]. Doctor's thesis. Kyiv [in Ukrainian].

Kalmykova, L.A., \& Kalmykov, G.V. (2015). Konceptualnye podhody k sovershenstvovaniju psihologicheskoj podgotovki budushhih pedagogov [Conceptual approaches of improving the psychological training of future teachers]. In L.A. Baykova, N.A. Fomina \& A.N. Sukhov (Eds.), Proceedings from PPRDCS PNIIE' 15: VII Mezhdunarodnaja nauchno-prakticheskaja konferencija «Pedagogika $i$ psihologija kak resurs razvitija sovremennogo obshhestva: problemy setevogo vzaimodejstvija v inkljuzivnom obrazovanii» - The $7^{\text {th }}$ International Scientific and Practical Conferences «Pedagogy and Psychology as a Resource of the Development of Contemporary Society: Problems of Network Interaction in Inclusive Education» (Ryazan, October, 8-10 ${ }^{\text {th }}$, 2015) (pp. 238-243). Rjazan: Rjazanskij gosudarstvennyj universitet imeni S.A. Esenina [in Russian].

Kalmykova, L.O. (2016). Rozvytok komunikatyvnoi osobystosti v umovakh smyslovoi vzaiemodii [The Development of Communicative Person in Conditions of Semantic Interaction]. Pereyaslav-Khmelnitskyi: Vydavnychyj Dim «Slovo» [in Ukrainian].

Kihlstrom, J.F., \& Cantor, N. (2017). Social Intelligence. In R.J. Sternberg \& S.B. Kaufnan (Eds.), The Cambridge Handbook of Intelligence (Chapter 28, pp. 564-581). Cambridge: Cambridge University Press. https://doi.org/10.1017/ CBO9780511977244.029

Kim, S., Yoon, M., Kim, W., Lee, S., \& Kang, E. (2012). Neural Correlates of Bridging Inferences and Coherence Processing. Journal of Psycholinguistic Research, 41 (4), 311-321. https://doi.org/10.1007/s10936-011-9185-z

Kudryavtseva, N.A. (1995). Edinstvo intellekta [The Unity of the Intelligence]. St. Petersburg [in Russian].

Rubskyi, V.M. (2019). Communication levels of the individuals. Anthropological Measurements of Philosophical Research, 16, 24-32. https://doi.org/10.15802/ ampr.v0i16.150217

Snyder, M. (2016). Oprosnik sposobnosti $k$ upravleniju samoprezentacii $v$ obshhenii [Questionnaire to Diagnostic the Ability to Manage Self-Presentation in the Process of Communication]. URL: https://www.google.com/url.kspu.edu [in Russian].

Tillman, R., \& Louwerse, M. (2018). Estimating Emotions Through Language Statistics and Embodied Cognition. Journal of Psycholinguistic Research, 47 (1), 125-138. https://doi.org/10.1007/s10936-017-9522-y 
Психолінгвістичні особливості розвитку комунікативної..

Zasekina, L.V. (2006). Strukturno-funktsionalna orhanizatsiia intelektu osobystosti [Structural-functional organization of intelligence of the person]. Extended abstract of Doctor's thesis. Kyiv [in Ukrainian].

\begin{abstract}
АНОТАЦІЯ
Метою статmі було проаналізувати психолінгвістичні особливості розвитку комунікативної компетентності в структурі соціального інтелекту у вчителів та директорів шкіл сучасного українського суспільства.

Методи дослідження. Для розв'язання поставлених в роботі завдань використовувалися такі теоретичні методи дослідження: категоріальний, структурно-функціональний, аналіз, систематизація, моделювання, узагальнення. Також використано емпіричні методи - спостереження, бесіда, тестування - для вивчення структури комунікативної компетентності та соціального інтелекту педагогів; психолого-педагогічний експеримент у формі дослідження срормованості структури комунікативної компетентності та соціального інтелекту педагогів.
\end{abstract}

Результати дослідження. У змісті комунікативної компетентності вчителів ми виділяємо здібності оптимізації міжособистісних взаємостосунків в групі; соціальну сенситивність; сукупність комунікативно-значущих умінь, паттернів поведінки і технік спілкування; комунікативний потенціал; інтерпретативну компетентність. У педагогів із низьким рівнем розвитку комунікативної компетентності нами діагностовано комунікативні невдачі, зумовлені порушеннями орієнтацій адресанта на процес комунікації: немотивована зміна мовленнєвих стратегій, ментальних орієнтацій та регістру мовлення; недотримання адресантом постулатів спілкування; неврахування адресантом мовленнєвих засобів, які є носіями максими такту; невдалий вибір адресантом тону та регістру спілкування. Сфрормульовано скрипти рольового дейксису, експліцитних та імпліцитних прагматичних констативів у структурі комунікативної компетентності педагога, розкрито їхній зміст.

Висновки. Встановлено психолінгвістичні особливості розвитку комунікативної компетентності вчителів та директорів шкіл: композитна оцінка комунікативної компетентності вчителя позитивно корелює із соціальним інтелектом, рефрлексивними та емпатійними особистісними здібностями; комунікативна компетентність вчителя залежить від актуалізації в iї структурі скриптів рольового дейксиса, експліцитних і імпліцитних прагматичних констативів та ін.

Ключові слова: комунікативна компетентність, процес спілкування, комунікативний потенціал, інтерпретативна компетентність, регістр спілкування, комунікативні невдачі, сочіальний інтелект. 
Psycholinguistic Peculiarities of the Development of Communicative...

Ивашкевич Эдуард \& Примачок Людмила. Психолингвистические особенности развития коммуникативной компетентности педагогов средних образовательных учреждений

\section{АННОТАЦИЯ}

Целью статьи было проанализировать психолингвистические особенности развития коммуникативной компетентности в структуре социального интеллекта у учителей и директоров школ современного украинского общества.

Методы исследования. Для решения поставленных в работе задач использовались следующие теоретические методы исследования: категориальный, структурно-функциональный анализ, систематизация, моделирование, обобщение. Также использованы эмпирические методы наблюдение, беседа, тестирование - для изучения структуры коммуникативной компетентности и социального интеллекта педагогов; психологопедагогический эксперимент для исследования структуры коммуникативной компетентности и социального интеллекта педагогов.

Результаты исследования. В структуре коммуникативной компетентности учителей мы выделяем способности оптимизации межличностных взаимоотношений в группе; социальную сензитивность; совокупность коммуникативно-значимых умений, паттернов поведения и техник общения; коммуникативный потенциал; интерпретативную компетентность. У педагогов с низким уровнем развития коммуникативной компетентности нами диагностированы коммуникативные неудачи, обусловленные нарушениями ориентаций адресанта на процесс коммуникации: немотивированная смена речевых стратегий, ментальных ориентаций и регистра речи; несоблюдение адресантом постулатов общения; недостаточный учёт адресантом речевых средств, которые являются носителями максимы такта; неудачный выбор адресантом тона и регистра общения. Сформулированы скрипты ролевого дейксиса, эксплицитных и имплицитных прагматических констативов в структуре коммуникативной компетентности педагога, раскрыто их содержание.

Выводы. Определены психолингвистические особенности развития коммуникативной компетентности учителей и директоров школ: композитная оценка коммуникативной компетентности учителя положительно коррелирует с социальным интеллектом, рефлексивными и эмпатийными личностными способностями; коммуникативная компетентность учителя зависит от актуализации в её структуре скриптов ролевого дейксиса, эксплицитных и имплицитных прагматических констативов и др.

Ключевые слова: коммуникативная компетентность, процесс общения, коммуникативный потенциал, интерпретативная компетентность, регистр общения, коммуникативные неудачи, социальный интеллект. 